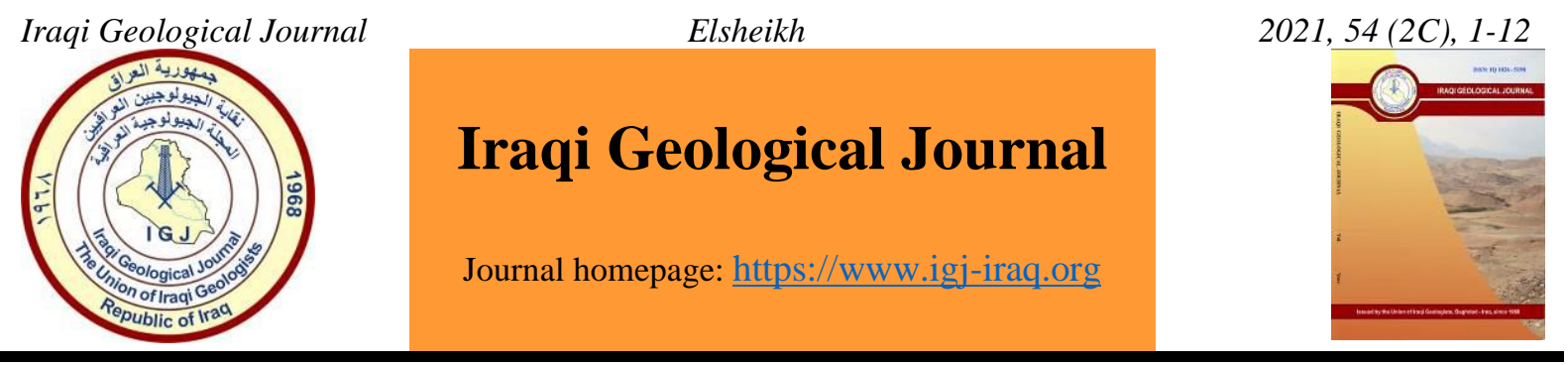

\title{
Seismic Stratigraphic Analysis and Hydrocarbon Potential of Miocene- Quaternary Deposits in the Western Nile Delta Basin
}

\author{
Mahmoud Elsheikh ${ }^{1, *}$ \\ 1 Faculty of Geology, Lomonosov Moscow State University, Moscow, Russia \\ * Correspondence: m.elsheikh90@gmail.com
}

Received: 18 January 2021; Accepted: 8 July 2021; Published: 30 September 2021

\begin{abstract}
This study focuses on the subsurface Miocene-Pleistocene sedimentary sequence of the Western Delta of DeepSea field. Analysis of seismic, based on obtainable well data, and seismic data, allows us to divide the studied successions into two mega sequences: Pre and Post Messinian complexes resulting in transgressive-regressive sedimentation cycles of sea level during the evolution of the Miocene -Pleistocene subsurface sedimentary sequence. The Relative level of the sea was extremely falling in the time of the Messinian period, although it was largely rising at the time of the lower to Middle Pliocene. Pre-/Messinian complex encompasses the Miocene strata, while the Post-Messinian complex consists of a thickness pattern of deposits in the time of Pliocene to Pleistocene and ended up with Holocene. The comprehensive study presented here divides these complexes into several orders of sea level cycles. Pre and Post-Messinian complexes are consisting of several third-order cycles, which is called a depositional sequence, hence the thickness pattern starts from Sidi Salem Formation and ends up with Mit Ghamr Formation (Pleistocene). The interpreted anticline represents a characteristic overlap that can create an appropriate structural trap for hydrocarbons in the sandy intermission of the formations of the Western Deep-Sea Delta field such as Kafr El Sheik siliceous clastic. Besides, the recognized individual and various hidden routes, such as channel and sub-channel in the Pre-Messinian complex are approved for additional inspection to discover hydrocarbons.
\end{abstract}

Keywords: Seismic analysis; Nile delta basin; Neogene-Quaternary succession; Miocene-Quaternary deposits

\section{Introduction}

The Nile Delta is one of the major hydrocarbon regions in Egypt. Like other deltas in the world, the Nile Delta has attracted the attention of many major oil companies. The Nile Delta Offshore area has immense exploration potential with existing commercial oil and gas fields in and around this basin. The Nile Delta is considered to be a suitable place for alluvial kinds of channel sediments, especially in the Pliocene and Miocene times. In the deep waters of the Mediterranean from south to north, numerous inclined channel deposits were created.

The seismic and sequence stratigraphy is a good tool for the interpretation of the hydrocarbons and oil reservoir (Alsultan et al., 2021). The genesis of the basin was created as a result of rifting in the Passive continental margin of Egypt during the upper Jurassic/lower Cretaceous geologic period, then a

DOI: $10.46717 /$ igj.54.2C.1Ms-2021-09-20 
basin is created after rifting by thermal subsidence which is known as Nile Delta Basin (Dolson, et al 2001). It comprises a province of more than $248,000 \mathrm{~km} 2$ of the Mediterranean Sea in the east.

The Nile Delta Basin possesses more than $6.5 \mathrm{~km}$ thick of the Upper Paleogene-Pleistocene clastic deposits (Aal et al., 2000), which were carried by the Nile River with a length of $6825 \mathrm{~km}$ emptying into the Basin in the Mediterranean Sea, In the same manner, a Mesopotamian basin is also covered by the Quaternary fluvial-plain deposits of the Tigris and Euphrates rivers with lengths of 1,900 and $2800 \mathrm{~km}$ respectively under this cover, anticlines, and horst lie and are mainly related to long-lived paleostructures (Handhal et al., 2020), Also in Nile delta basin exists long-lived paleo-structures. It is well known that the Mesopotamian basin is considered to be an important province of hydrocarbon in Iraq also Nile delta basin is one of the most important hydrocarbon provinces in Egypt. It contains structural and combined traps with undiscovered plays and prospects. The aim of the work here lies in determining the prospects of these alluvial channel deposits, developed in the western part of the Nile delta, and highlights the hydrocarbon perspectives of the Miocene thickness pattern in the Western Delta of DeepSea (WDDM) block depending on the persistent interpretation of the stratigraphy and architecture of the basin (Fig.1). The work will be based on seismic materials obtained in the process of 3D- surveying in the field area.

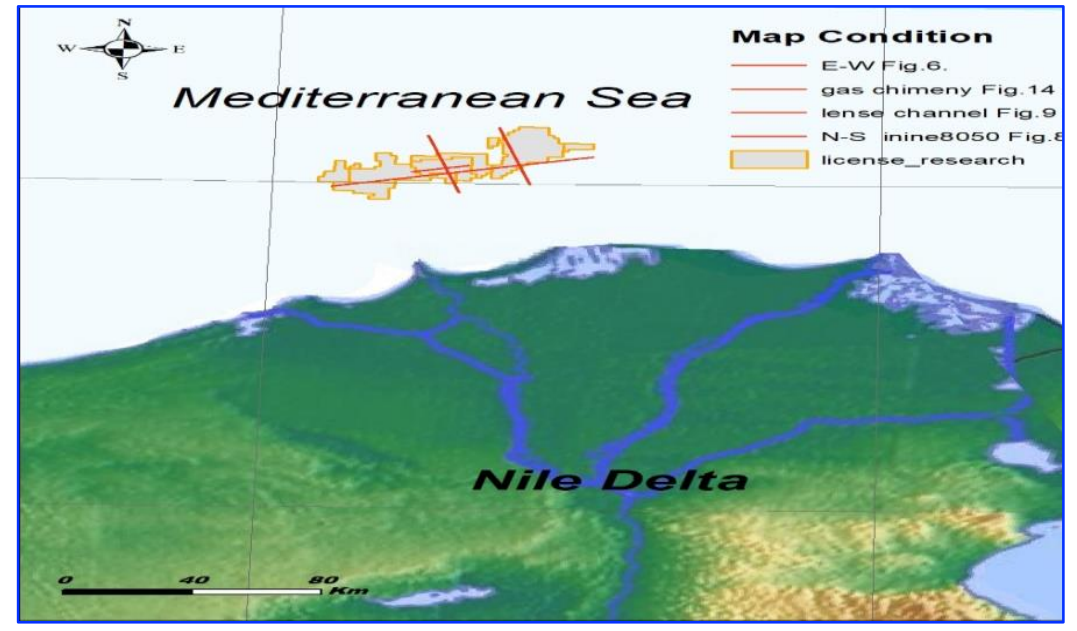

Fig. 1. Location western delta of deep-sea (WDDM) field

\section{Geological Setting and Stratigraphy}

Within the plate tectonic development of the eastern Mediterranean and the Levant, The Nile Delta region is located. It is located on the northern edge of the African Plate, which extends from the subduction zone adjacent to the Cretan and Cyprus arcs to the Red Sea, which was ripped apart from the Arabian Plate. Alluvial deposits of Nile started in the Oligocene, the evolution of the sedimentary cover in the basin was determined by terrigenous material coming from the northeastern regions of the African continent - the Ethiopian plateau and Sudan. The sequence of Pliocene-Quaternary sediments in the Nile Delta is divided by regional faults of both latitudinal and meridional, and northwestern (Temsah trend) and northeastern (Rosetta trend) striking (Sestini,1989). The faults oriented in the NW and NE directions are distributed mainly within the northeastern and northwestern sectors of the delta, respectively (Abd-Allah et al., 2012) (Fig2).

They are also distinguished at the southern border of the vast field of development of the Messinian salts, where they intersect with each other. The onshore part of the delta is dominated by latitudinal faults. From here, they stretch to neighboring areas in the North-East of Egypt. The tectonic setting of the sedimentary section is examined by displaying data and clarifying the most characteristic seismic horizons in the WDDM field. This helps illuminates the factors and conditions that control the deposition in the basin during Miocene-Holocene. From Miocene till the Holocene epoch in Nile Delta basin is 
considered to be a siliceous-clastic sequence, including the base Sidi Salem, to top Mit Ghamr formations. This stands on the immense activeness of the exploration of oil and gas in the offshore and onshore part of the Nile Delta, which helped to understand the stratigraphic column of the Nile Delta (Fig.3). Sea-level drop takes place during Messinian, which led to the quick withdraw of the Late Tortonian Sea to the north, leading to a formation of thick salt deposits all through the whole Mediterranean Sea, this geologic event is known as the Messinian Salinity Crisis (Barber,1981). In the Levant Basin in the Eastern part of the Mediterranean Sea, the evaporites reach a thickness of almost 2 $\mathrm{km}$ and interbedded with up to four mixed layers (Feng et al., 2016)

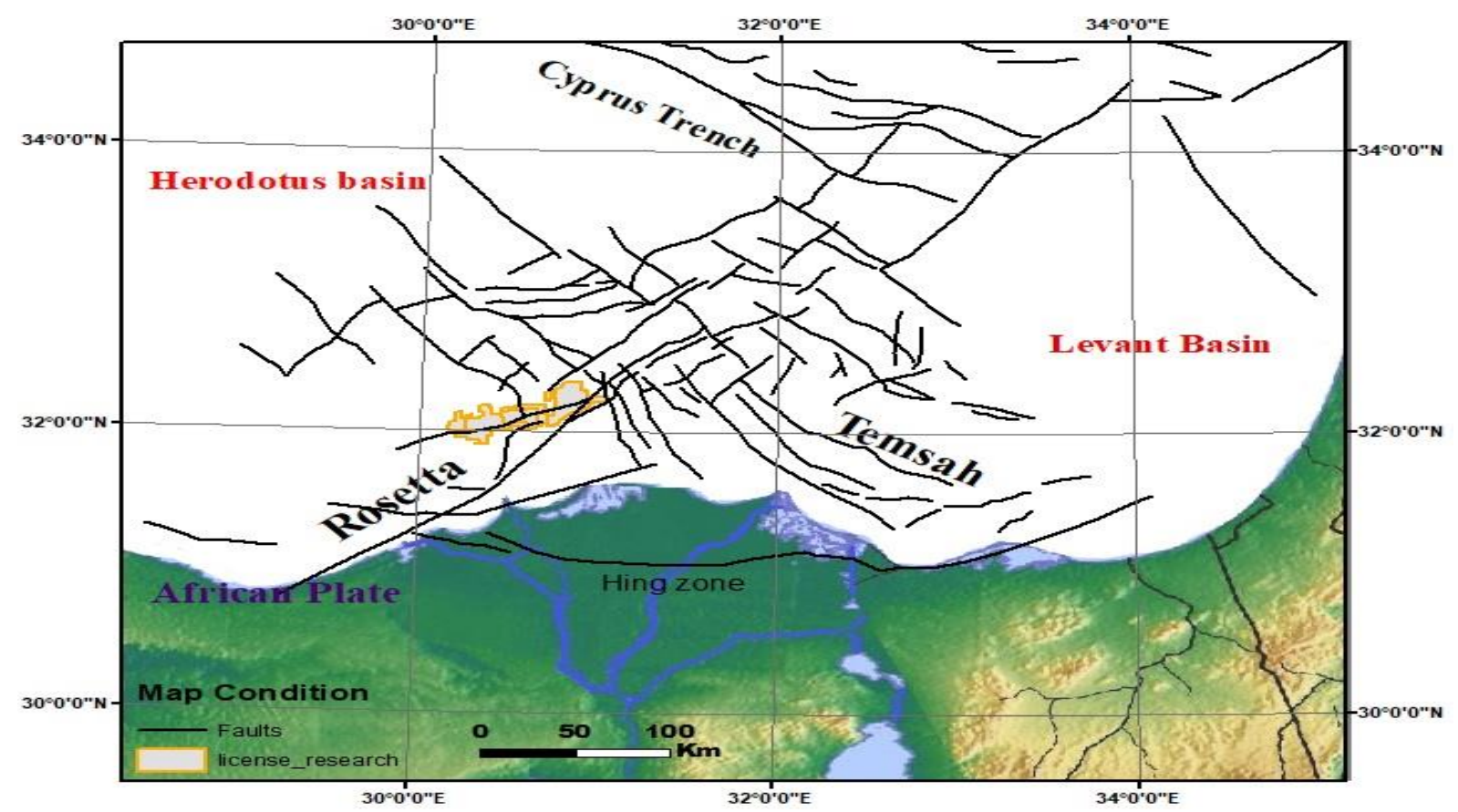

Fig. 2. Map of the structural area of the Mediterranean Nile Delta, Yellow Box WDDM location (Aal et al., 2000)

Paleozoic formations of the Nile Delta basin have not been confronted by drilling because they existed in unreachable depths. Cenozoic is composed of sediments ranging in age from Eocene to Holocene. Sediments during the Eocene are expressed by thin series of marly limestone represented, while deposition during Oligocene which represented by the Tineh Formation, consists of a very thick series of marine to fluvio-marine shale and sandstone interbeds, it accounts for Late Oligocene and Early Miocene. The Tineh Formation unconformably underlies the Qantara Formation. the depositional environment during The Miocene geologic period demonstrates open marine deposits at the start with a ravenous evaporitic sequence at the end. Thickness of Miocene and Pleistocene hydrocarbon bodies increase towards the shelf (Fig.4). The Miocene cycle is introduced by the Sidi-Salem and Qawasim Formation. The Qawasim Formation unconformably overlies the Sidi-Salem Formation and underlies the Abu Madi evaporites (Kamel et al., 1998). North of the hinge line in the Nile delta basin Developed Plio-Quaternary section which is considered a mega sequence of marine sediments up to more than $3000 \mathrm{~m}$ in thickness. The Pliocene cycle is divided into three formations, from the bottom to top; the Abu Madi, Kafr El Sheikh, and El Wastani formations.

The late Miocene is represented by Abu Madi Formation. It is the gas-producing horizon of the Nile Delta fields. The maximum Abu Madi thickness is 480m (Nashaat, 1992). This formation primarily consists of sandstone with siltstone intercalations and shale interbeds. Early-Middle Pliocene is 
represented by Kafr EL sheik Formation with a maximum thickness of 1839 m (Nashaat, 1992). It is consisting of claystone and siltstone sequences with thin sandstone units (Schlumberger, 1984) and El Wastani Formation represents the Late Pliocene period. It represents a transitional depositional environment between the outer shelf of the underlying Kafr El Shiekh Formation and coastal to continental sands of the overlying Mit Ghamr Formation.

\begin{tabular}{|c|c|c|c|c|c|c|}
\hline Epoch & \multicolumn{2}{|c|}{ Age } & Formation & Lithology & & $\begin{array}{l}\text { Fields/ } \\
\text { Discoveries }\end{array}$ \\
\hline $\begin{array}{l}\text { Pleistocene- } \\
\text { Holocene }\end{array}$ & & & \begin{tabular}{|l} 
Bilqas / Mit Ghamr \\
\end{tabular} & & & Rosetta, WDDM, \\
\hline Pliocene & Late & Piacenzian & El Wastani & & 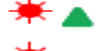 & area \\
\hline \multirow{5}{*}{ Miocene } & & Messinian & $\begin{array}{l}\text { Abu Madi } \\
\text { Rosetta }\end{array}$ & & & $\begin{array}{l}\text { Abu Qir/El King } \\
\text { Abu Madi/Baltim }\end{array}$ \\
\hline & Late & Tortonian & Qawasim Wakar & & & $\begin{array}{l}\text { Wakar, } \\
\text { port Fouad }\end{array}$ \\
\hline & Middle & Serravallian & Sidi Salim & & 本 & $\begin{array}{l}\text { Temsah/Akhen } \\
\text { El Tamad }\end{array}$ \\
\hline & Lower & Burdigalian & Qantara & & & Raven \\
\hline & & Aquatinian & & & & \\
\hline \multirow{2}{*}{ Oligocene } & Late & Chattian & \multirow{2}{*}{ Tineh } & & - & $\begin{array}{l}\text { Tineh } \\
\text { Salamat } \\
\text { Atoll }\end{array}$ \\
\hline & Early & Rupelian & & & & $\begin{array}{l}\text { Hedwa } \\
\text { Notus }\end{array}$ \\
\hline \multicolumn{4}{|l|}{$\begin{array}{l}\text { Eocene } \\
\text { Paleocene }\end{array}$} & & & - Base Tertiary \\
\hline Jurassic & & & & 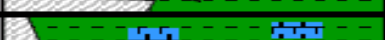 & $\mathbf{x}$ & $\begin{array}{l}\text { Zohr } \\
\text { (Western Desert) }\end{array}$ \\
\hline
\end{tabular}

Fig. 3. Stratigraphic column of the Nile Delta and the hydrocarbon system in the area (Schlumberger,1984 Monir, and Shenkar, 2017).

\section{Materials and Methods}

The concession is located 50-100 km offshore and covers $6,150 \mathrm{~km}^{2}$ of the northwest margin of the Nile Delta. It is situated offshore far from northeast of Alexandria city with $120 \mathrm{~km}$ and with water depths ranges from 256 to $855 \mathrm{~m}$ (Samuel, 2003). The WDDM concession in the Mediterranean includes 22 gas fields, of which 14 (Saffron, Scarab, Sapphire, Siena, Simian gg, ...) are in production. To develop the seismic stratigraphy interpretation, based on sequence stratigraphy we used migrated 3D seismic data in the SEGY format in this study that includes 3D surveys in the WDDM in software Petrel. Based on the geometry of the reflectors, amplitude stacking patterns, continuity, stacking patterns, and seismic facies, we interpreted an average of 10 representative reflectors in addition to, Collection and systematization of the ArcMap database based on published data of the Nile Delta basin such as the literature data, various maps were obtained - structural, tectonic, location of seismic profiles, well logs. These maps were spatially referenced, based on which wells and seismic profiles were digitized. Then a correlation of the 15 well logs was carried out by remarking the top of each formation through their $\log$ response (Fig.4). Seismic well tie carried by Sidi Ghazy-Well through Petrel software which allows tying time data (seismic data) to depth data (well data), Impedance log and reflection coefficients are generated from the sonic log. The reflection coefficients are convolved with a seismic wavelet (Ricker) to produce a synthetic seismic trace with a correlation coefficient equal to 0.47 . The value of the correlation coefficient is small because the Sidi Ghazy well is located onshore about $100 \mathrm{Km}$ far from the License block, subsequently, the main horizon Formation tops were traced (Fig .5). 


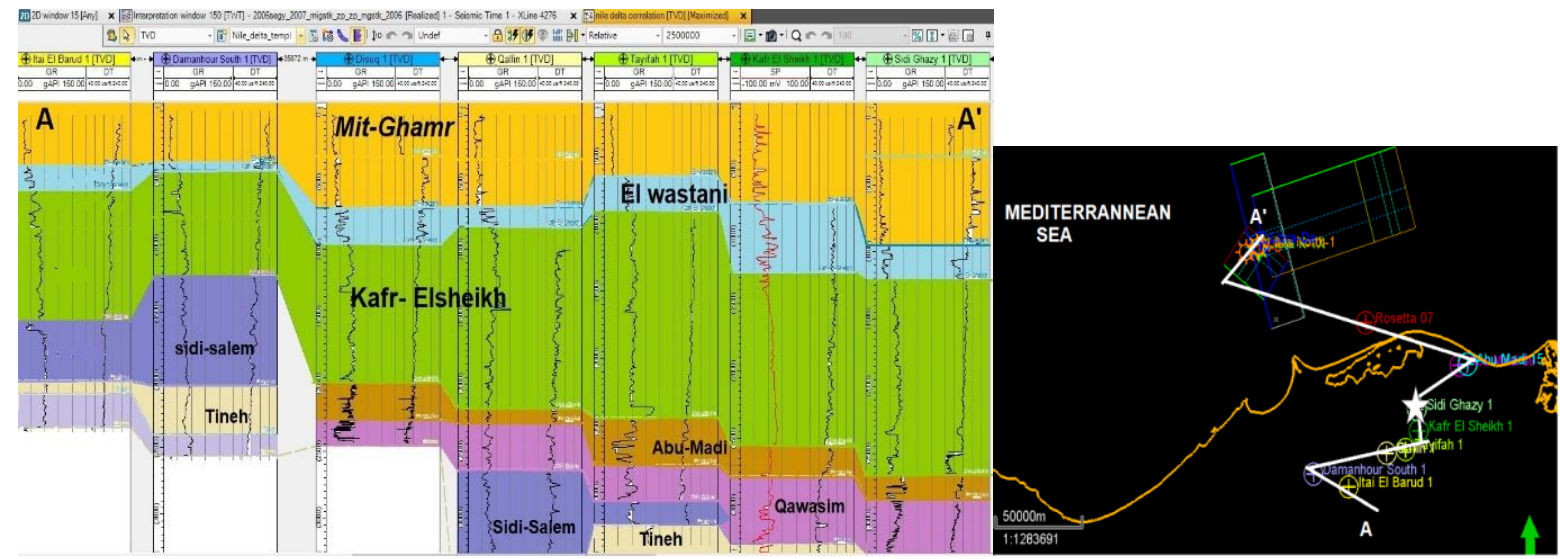

Fig. 4. Well correlation through WDDM field, note the increase of thickness of Pilo-Pleistocene formation in sea direction

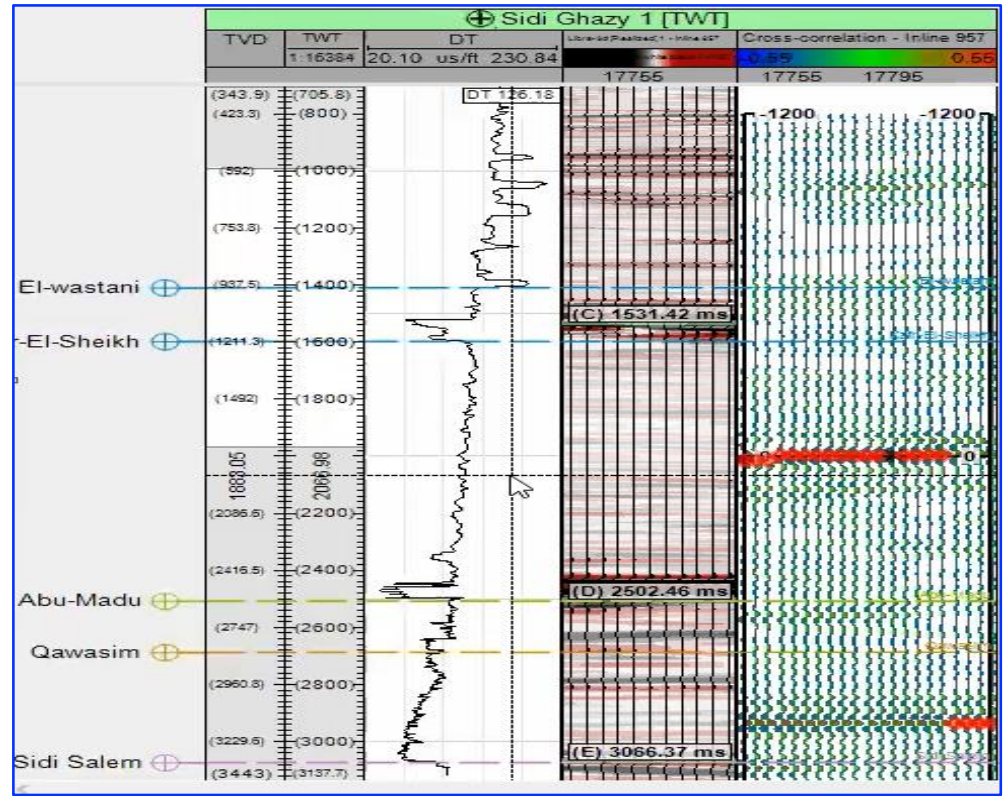

Fig.5. Sonic log of the Sidi Ghazy well

Eventually, seismic stratigraphic methods of analysis were carried out to better understand the stratigraphy of subsurface formations of the WDDM field. Analyses were carefully done by observing high and low amplitude events relationship with either the top or bottom of seismic strata sequences his approach is a sequel to the opinion of Vail et al. (1977b) that unconformities enveloped packages of reflectors are called seismic sequences. These foundational concepts of boundaries and sequence delineation have been utilized to analyze subsurface data from the WDDM field. Key stratigraphic intervals were delineated using sequences with similar characteristics which often are bounded by unconformity surfaces (Fig.6).

Then analysis of Miocene-Pleistocene Seismic sections in the WDDM field was carried out by remarking and picking the distinct seismic horizons and main faults that affect these horizons, along with the available three-dimensional seismic. Based on the available seismic profiles, 6 seismic horizons were traced: the base and top of the Serravallian Formation (Sidi-Salem), Head Formation of Wakar (Tortonian), Head Formation of Abu-Madi (Messinian), and Pliocene top Formation (Kafr Elsheikh and El Wastani). These horizons with the faults were mapped. 


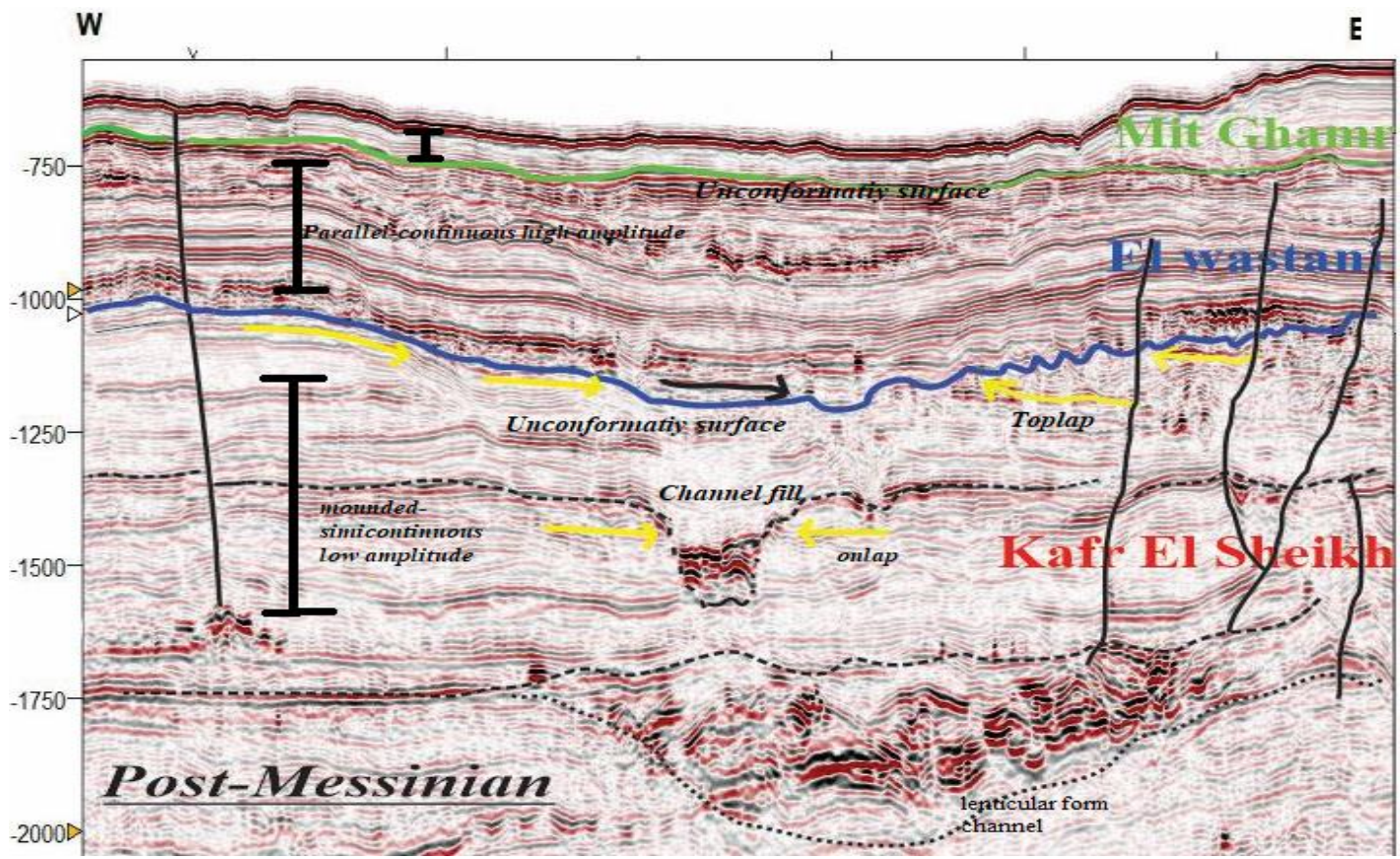

Fig. 6. Cross-line shows key stratigraphic intervals and boundary in The WDDM field

\section{Results}

The entire studied section is divided into two main mega sequences separated by the main surface of the Messinian unconformity (Abu-Madi Formation), which is a clear, strong reflector of large amplitude (Fig.7).

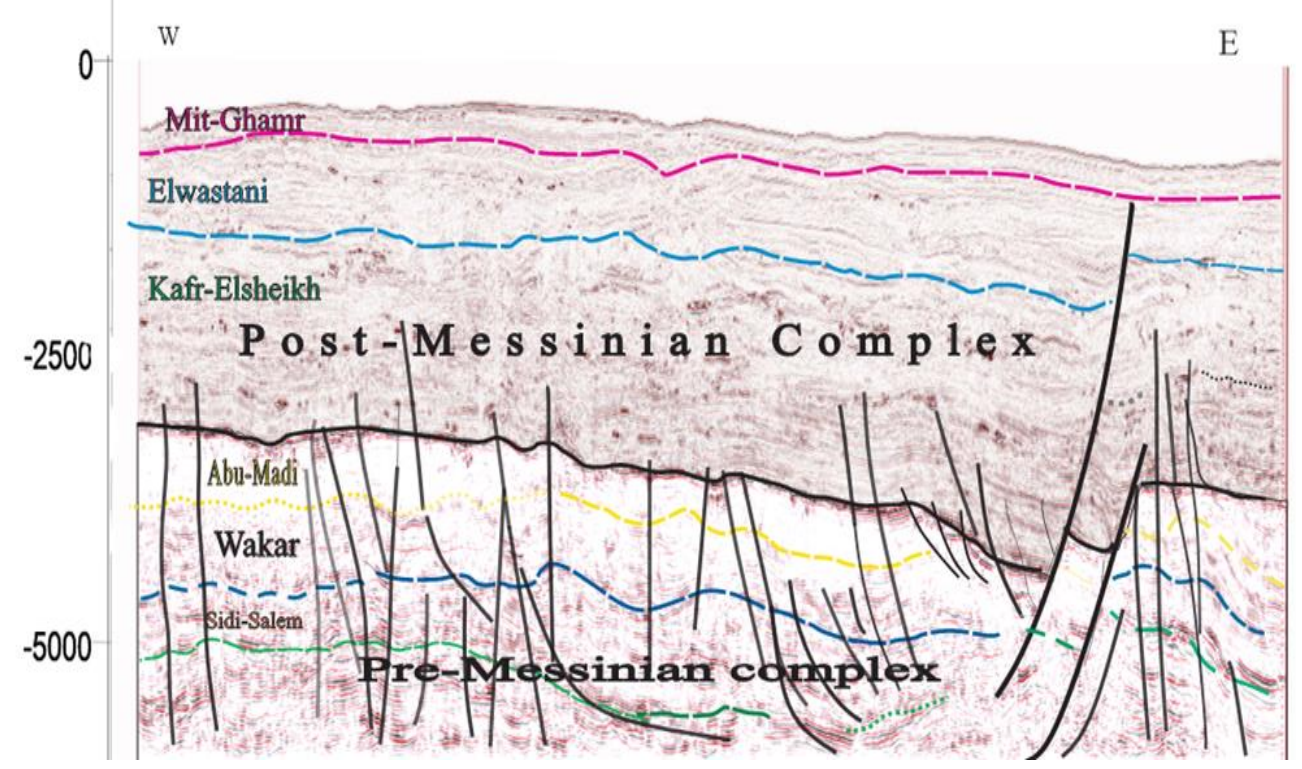

Fig. 7. E-W cross-section through the Study Area

In the WDDM field, The Pre-Messinian complex comprises Miocene formations which include Sidi-Salem and Wakar Formations. The Sidi-Salem Formation base is characterized by a flanking-lateral prolonged reflector which represents a very extreme amplitude with an unconformity surface in a depth that ranges from $4650 \mathrm{~ms}$ to $5000 \mathrm{~ms}$, where the Sidi-Salem Formation top is mainly assumed to be a prevalent unconformity surface through the Basin. The top of the Sidi-Salem in the WDDM field is 
expressed by a not entirely continuous reflector with low-key amplitude, which differs in depth from 3700 to $4650 \mathrm{~ms}$. The base and top of this formation can be defined from seismic as the overlying seismic reflections and toplapping terminations of the underlying reflectors. The Wakar Formation Top is indicated on seismic sections from $3275 \mathrm{~ms}$ to $3700 \mathrm{~ms}$. Wakar Formation is characterized by discontinuous, chaotic low amplitude reflections.

The Messinian Unconformity Surface (Top Abu-Madi Formation) is a large-scale significant unconformity surface that extends throughout the entire Mediterranean Basin, which serves as an MSC the Messinian salinity crisis in the Messinian period, The Messinian unconformity surface is regarded to be a vital unconformity that extends across the Basin in WDDM field, and discrete upper Miocene section out of the lower Pliocene covering section. It is characterized by a seismic reflector, with a severe amplitude, strong continuity, and high frequency.

The Post-Messinian Megasequence consists of a Pliocene-Pleistocene sedimentary succession, which includes from base to top as follows: starts from Kafr Elsheikh (early-Middle Pliocene), which is considered to be the thickest formation in the WDDM field, then El Wastani Formation, and Ends with the Mit Ghamr Formation (Pleistocene) (Fig.8).

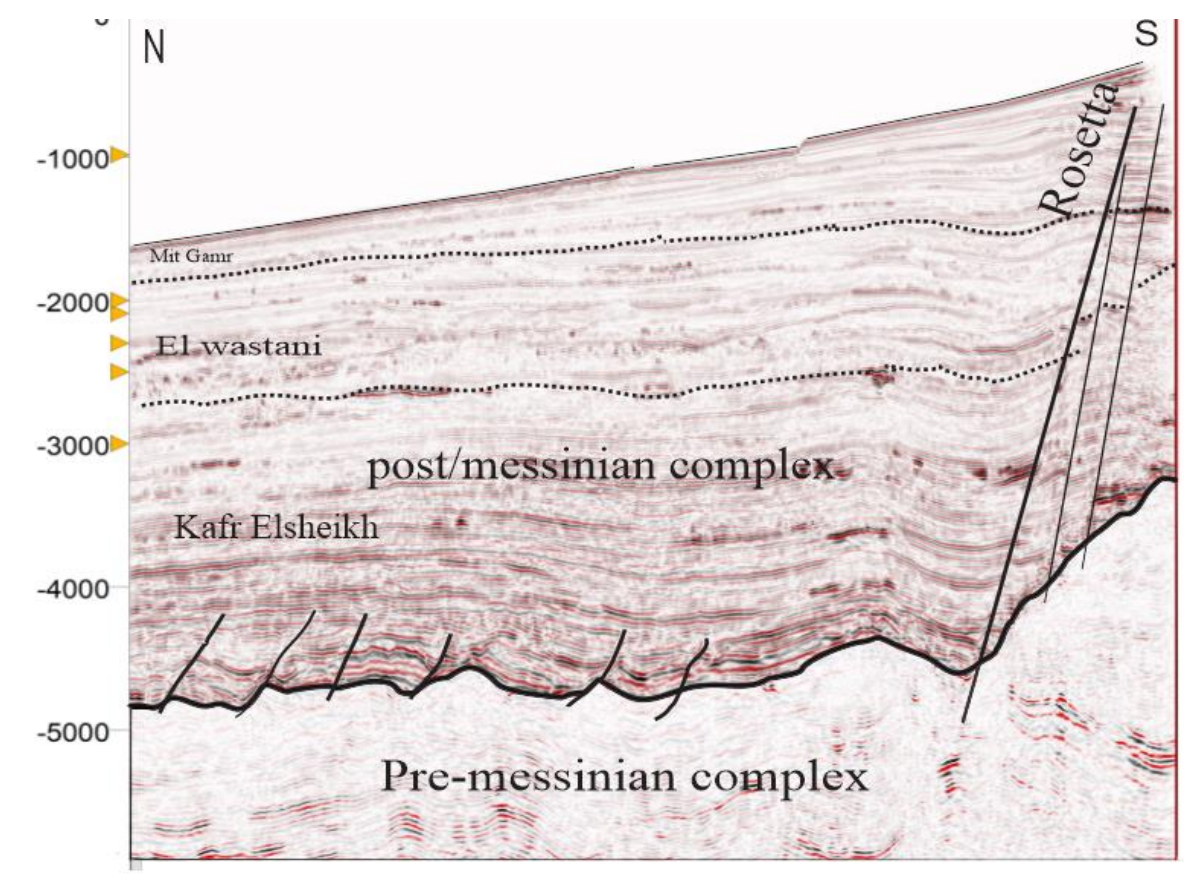

Fig. 8. N-S cross-section through the study area

From geophysical point of view (seismically), Kafr Elsheik Top can be easily traced due to the overlapping reflector terminations. At the bottom, transparent, translucent, and chaotic seismic facies are shown, while reflections in the middle sequence show reflections ranging from hilly to discontinuous and disorganized. These characteristics are probably associated with large deformation, which is possibly related to the aforementioned shale diapirism (Sarhan and Safa, 2019). Observed oblique seismic reflections associated with the fault block motion beside its plentiful planar flat surface. Each multiform or individual hidden channel has been found within the lenticular form Kafr Elsheikh Formation. These channels can be traced, as they appear as bright spots in seismic profiles in the western sector of the Nile delta basin (Fig.9). As a result of the probability of habitations of trapped gas immersed into the channels, faithfully like in other offshore fields located in the center of the Nile delta basin such as Temsah filed (Safa et al., 2017) 


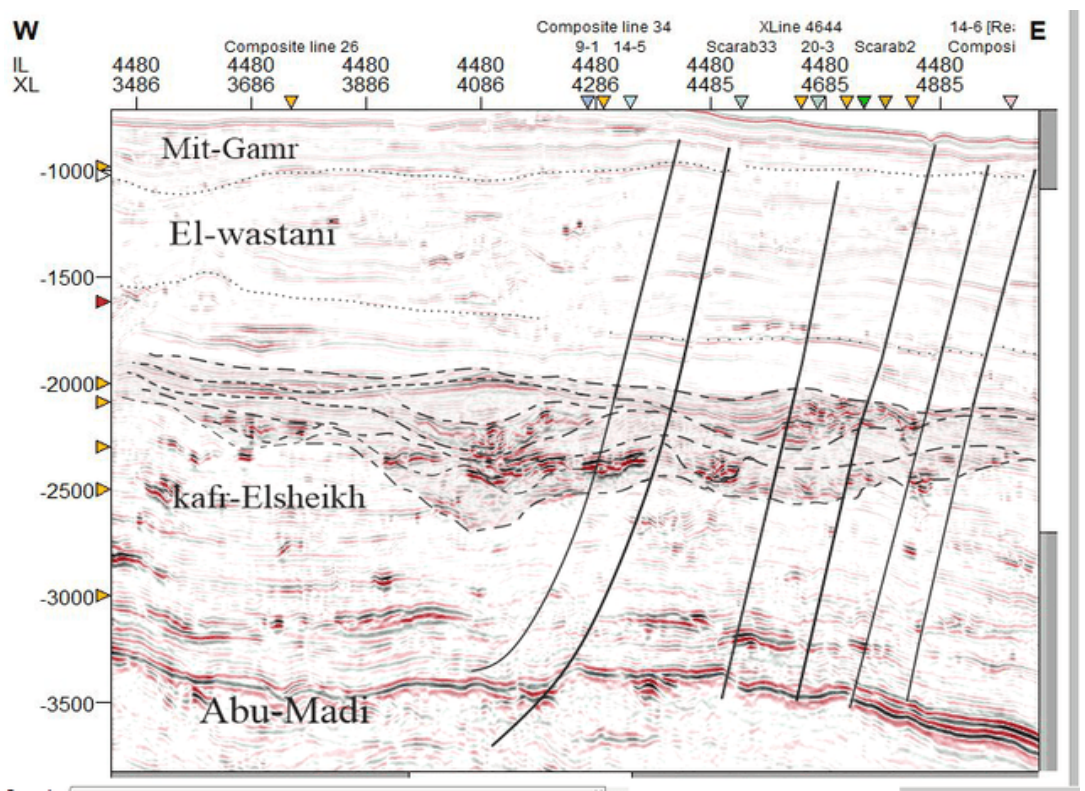

Fig. 9. Inline 4480 shows buried lenticular form channels in the Kafr-el sheik Formation

The Late Pliocene El Wastani Formation is bounded at the base of the Kafr Elsheikh Formations, and in the upper part of MitGamr Formations, which is the lower surface of the Quaternary period. The internal seismic reflections of the El Wastani Formation are characterized by moderate to extreme amplitude continuous, parallel, and sub-parallel seismic facies. Pleistocene Formation (Mit Ghamr) is identified by continuous high amplitude parallel or subparallel seismic reflections. Time structural maps of top horizons were constructed and it shows a characteristic anticline of the northwest-southeast strike. This anticline is visible on seismic profiles. The time maps of Sidi Salim, Abu Madi, and El wastani Formations also show a steady rise in depth from southeast to northwest over the mapped area with major common faults crossing the El Wastani Fm, Kafr Elsheik Fm, and Sidi-Salem Fm in the WDDM field (Fig.10)
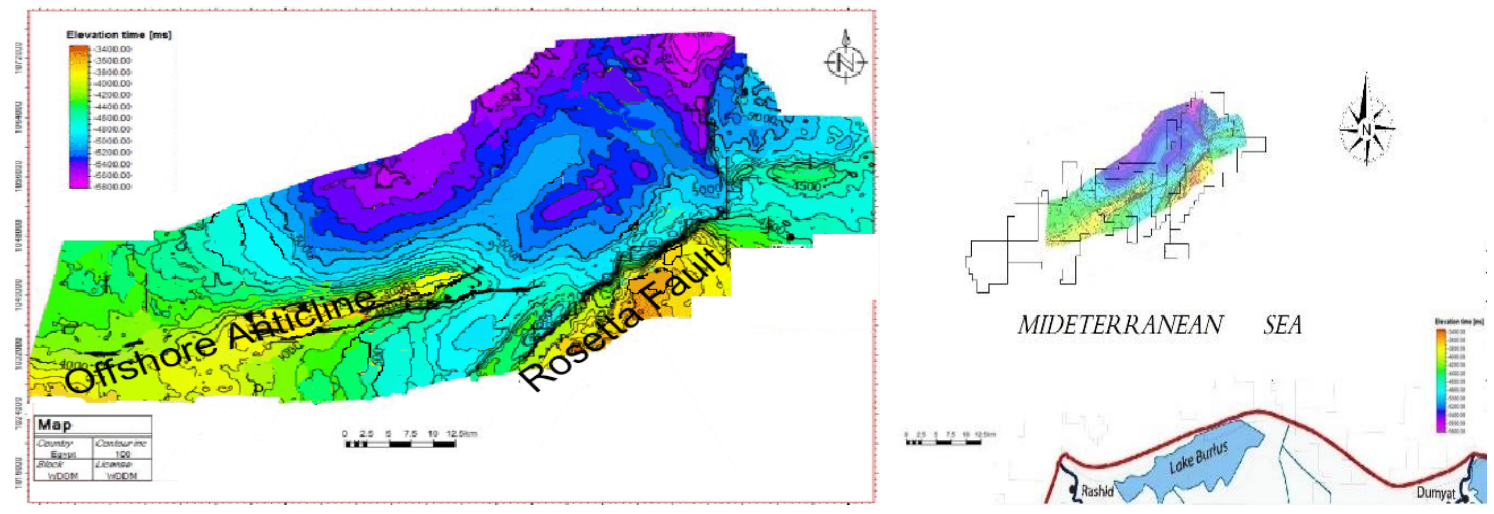

Fig. 10. The time structure map shows the main anticlinal uplift of the offshore part of the Nile Delta, known as NDOA, and the regional Rosetta fault

\section{Discussion}

In the WDDM field, the deposition pattern can be divided into 6 cycles of sea level cycles of the third order with a higher recurrence of transgression. In General, Eustacy is a change in the global sea level. It is a cyclic phenomenon. Six orders of sea level cycles are known from stratigraphic evidence. Each of the Third, fourth, and fifth-order sea level cycles model sequence deposition for petroleum exploration (Fig.11). As a result, Pre and Post-Messinian complexes is consisting of several third-order 
cycles, which is called a depositional sequence. The Relative level of the sea was extremely falling in the time of the Messinian period, in which thick salt deposits were created throughout the entire Mediterranean Sea and it is represented in the WDDM field by the Abu-Madi Formation Followed by a sudden rise afterward stillstand at sea level. The great rise of relative sea level was throughout the Early to Middle Pliocene, correspondingly this led to the accumulation and growth of the shale of the exterior shelf which was revealed by the formation of Kafr Elsheikh. The interpreted diapiric tectonics and faults within the Kafr Elsheikh Formation are expected to have an important function in controlling hydrocarbon accumulation in the interstratified sandstone deposits surrounded by the Kafr Elsheik shale Formation in the WDDM field. The western sector of the Nile Delta Basin possesses familiar traps of hydrocarbons that accommodate only gas reservoirs, with the absence of oil. The origin of the gas in the reservoirs is biogenic and thermogenic buried in channels in the formations such as Elwastani and Kafr El Sheikh (Sharaf et al., 2014). Pliocene alluvial Deepwater fan deposits are considered to be good reservoirs in the West Nile delta with the continuation of the canyon, which operated in the Pliocene time, there were Deepwater alluvial fan deposits.

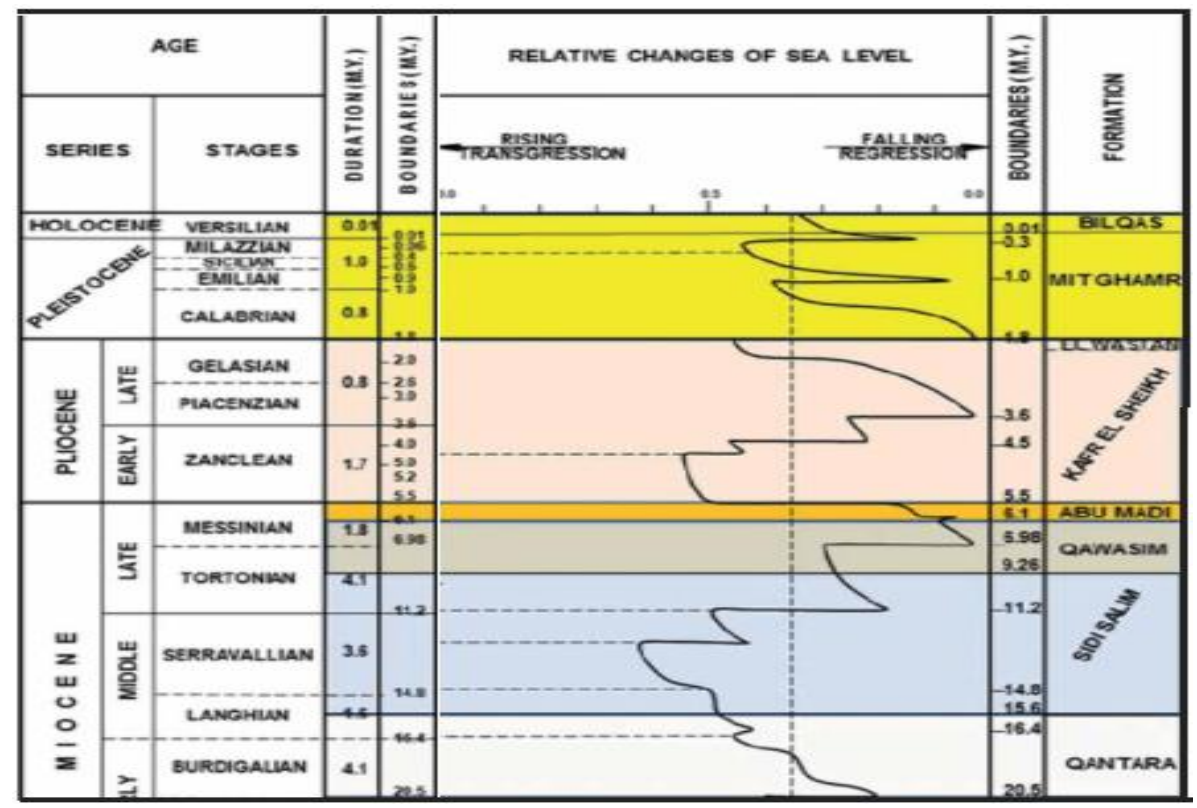

Fig.11. Sequence-chronostratigraphic chart of Nile Delta (Harms \& Wray 1990).

This area, which is covered with a dense network of seismic lines (3D survey), is separated from the eastern half of the delta by the Rosetta fault. Another large tectonic structure is the anticlinal uplift of the offshore part of the Nile Delta, known as NDOA (Fig. 10). In the analysis of seismic materials in the Upper Pliocene part of the section, systems of underwater valleys of various lengths were delineated, called Safron, Scarab, Serpent, Simian, and Sienna, that form structure stratigraphic hydrocarbon trap of buried meandering-Type channel (Fig. 12). The nature of the seismic reflections indicated that they were filled with clastic sediments, mainly sand. Several gas fields were discovered during later drilling in the El Wastani Formation. Gas chimneys, bright anomalies, and combined seabed appearance exist in the seismic profiles suggest the presence of the shallow biogenic gas, which migrated through routes to up the seafloor (Fig.14). The producing reservoirs in the WDDM field is only in post-Messinian successions, Therefore Messinian and Pre-Messinian successions considered to be a new target for hydrocarbons in the (WDDM) field, based on the seismic analysis it shows that they contain channels that can be traced with the help of seismic variance and RMS amplitude (Fig.13.). 


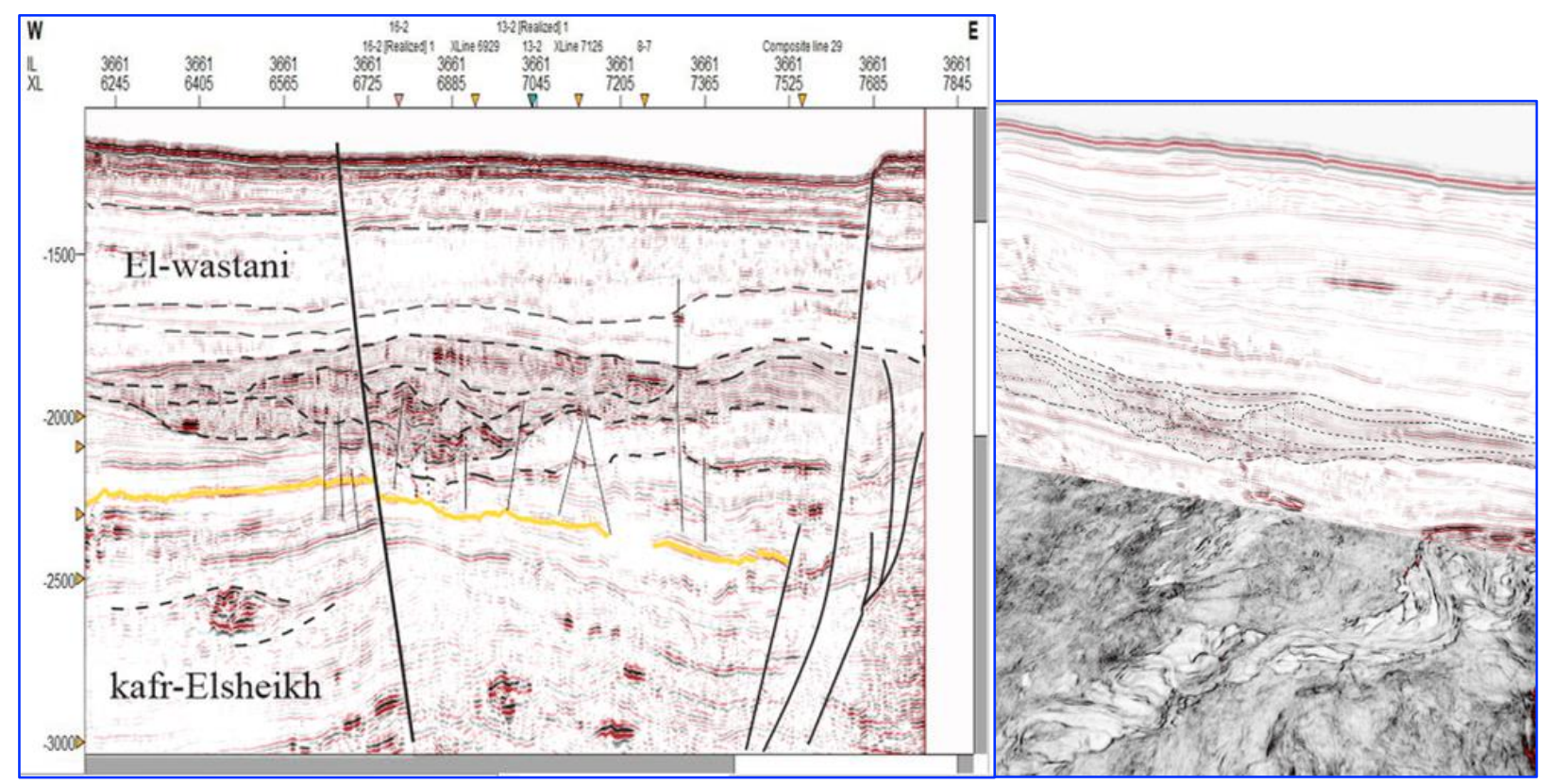

Fig. 12. Structure-stratigraphic hydrocarbon trap of buried meandering-type channel

The plays contain the same type of structure-stratigraphic trap that exists in Kafr Elsheikh. There is no well that has been drilled in Messinian and Pre-Messinian successions until 2018, Rashid Petroleum company (RASHPECTO) decided to drill the first well to target the Messenian Formation and it was a discovery. The Well shows a $32 \mathrm{~m}$ net pay of gas in $175 \mathrm{~m}$ of gross sand thickness in AbuMadi Formation at depth $5000 \mathrm{~m}$. It endorses the proceptivity of Pre-Messenian succession and stimulates further exploration in this succession in the WDDM field. Based on interpreted horizons and the detected collectors and available geochemical data. A 3D modeling will be conducted to better understand the migration path and determine the risk in this succession.
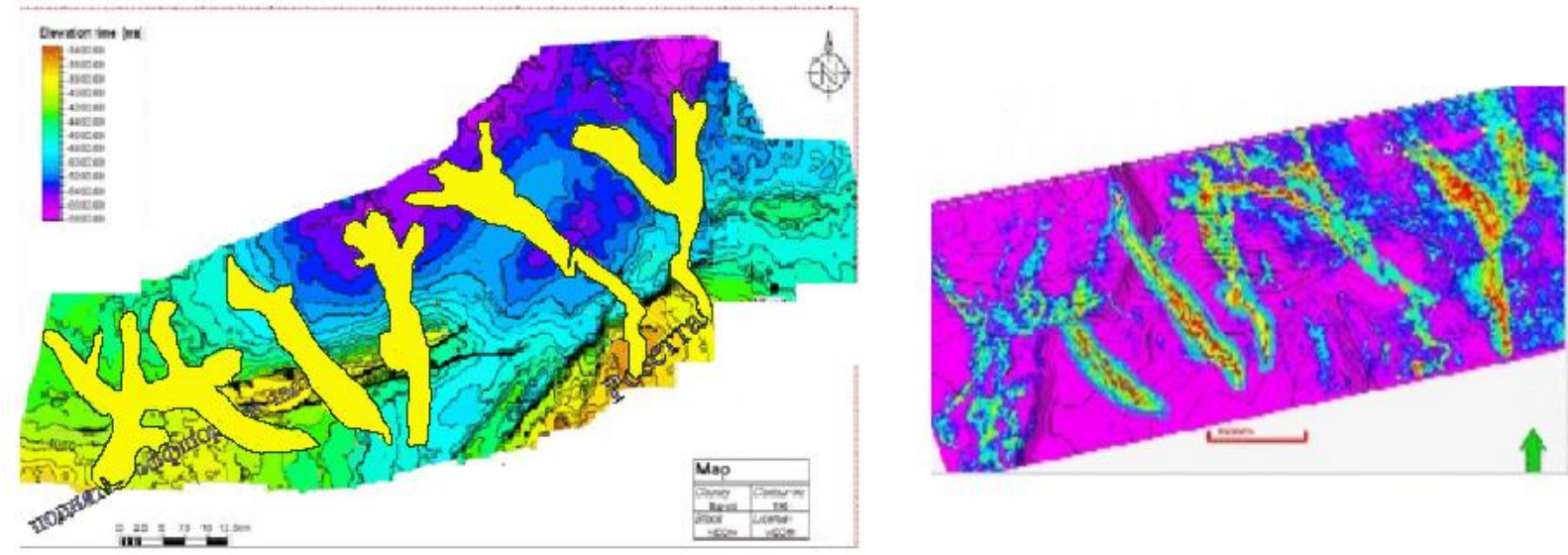

Fig.13. Reservoir potential of buried channels in top Sidi Salem time map (Pre-Messenian succession in the WDDM field 


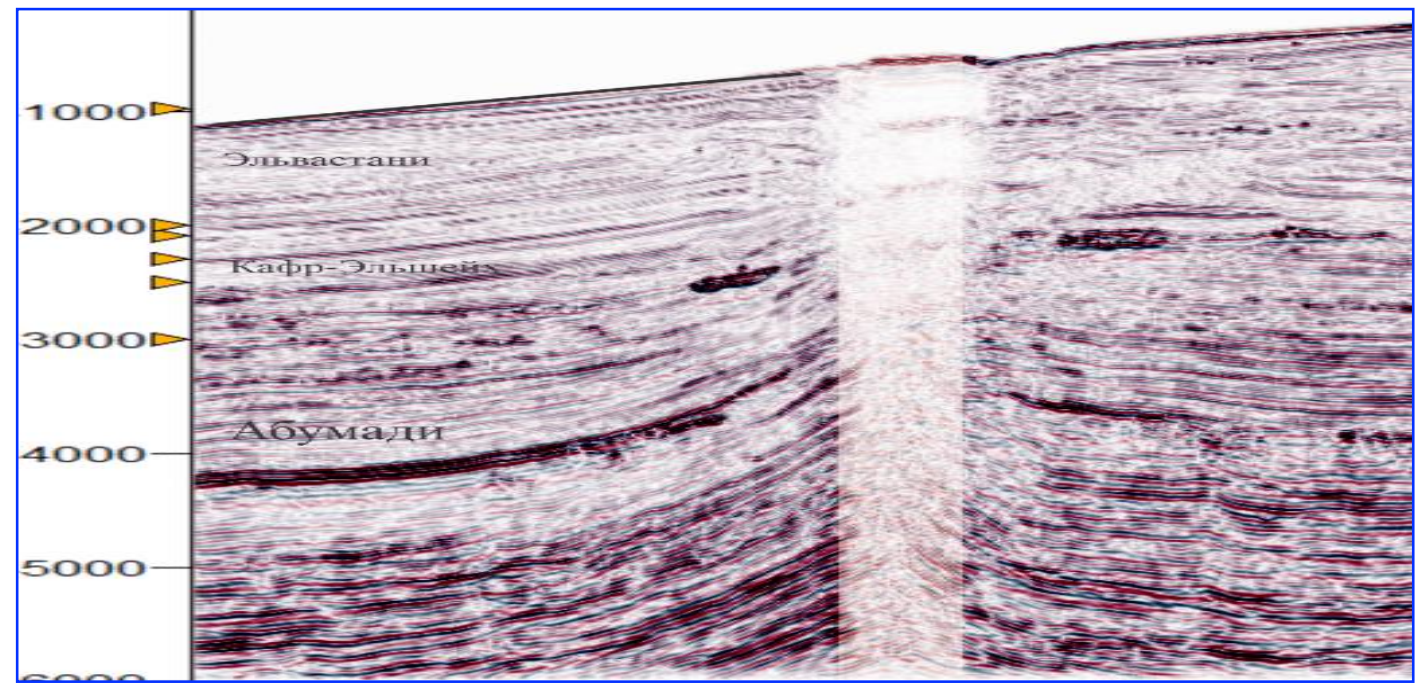

Fig.14.Gas chimney through the seismic section

\section{Conclusions}

The Analysis of gathered data in the WDDM field such as seismic lines of 3D cubes and well logging data, allows us to divide the thickness pattern of the basin into two mega sequences: Pre and Post Messinian complexes; as a result, sea level underwent 6 cycles of transgressive-regressive sedimentation during the evolution of the Miocene-Pleistocene period. Each multiform or individual hidden buried meandering-type channel has been found within the lenticular form. These channels can be traced, as they appear as bright spots in seismic profiles and are approved for additional inspection to discover hydrocarbons, Especially Pre-Messinian complex, which is considered for possible exploration to find more possible targets and prospects. The interpreted large tectonic structure is the offshore Nile Delta anticlinal uplift, which is a characteristic overlap that can create a competent and appropriate structural hydrocarbon trap in the sandy siliceous-detrital formations in the WDDM field.

\section{Acknowledgements}

The authors are very grateful to the Editor in Chief Prof. Dr. Salih M. Awadh, the Secretary of Journal Mr. Samir R. Hijab. and the Technical Editors for their great efforts and valuable comments.

\section{References}

Aal, A., El Barkooky, M., Gerrits, H., Meyer, M., Schwander, M. and Zaki, H., 2000.Tectonic evolution of the Eastern Mediterranean Basin and its significance for hydrocarbon perspectivity in the ultra-deep water of the Nile Delta, The Leading Edge, 19 (2000), 1086-1102.

Abd-Allah, A. M., Aal, M. H. A., and Ghandour, A., 2012. Structural characteristics and tectonic evolution of the northwestern margin of the Nile Delta, Egypt. Journal of African Earth Sciences, 68, 82-95.

Alsultan, H.A., Awadh, S.M., Al-Owaidi, M.R. and Al-Khafaji, A.J., 2021. Sequence Stratigraphy and Depositional Environment of the Zubair Formation in Rumaila Oilfields, Southern Iraq: Microfacies and Geochemistry. The Iraqi Geological Journal, 54(2B), 28-41.

Barber, P.M., 1981. Messinian subaerial erosion of the proto-Nile delta. Marine Geology, 44, 254.

Dolson, J. C., Shann, M. V., Matbouly, S., Harwood, C., Rashed, R., Hammouda, H., 2001. AAPG Memoir 74, Chapter 23: The Petroleum Potential of Egypt.1369 pp

Feng, Y.E., Ynkelzon, A., Steingberg, J., Reshef, M., 2016. Lithology and characteristics of the Messinian evaporite sequence of the deep Levant Basin, eastern Mediterranean. Marine Geology, 376, 118-131. 
Handhal, A. M., Al-Shahwan, M. F., \& Chafeet, H. A., 2020. Interpretation of hydrocarbon generation, migration and thermal history Of Mesopotamian Basin Southern Iraq based 1D Petromod software. The Iraqi Geological Journal, 53, 29-56.

Harms, J. C., Wray, J. L., 1990. Nile Delta. In: Said R (ed) The Geology of Egypt. Balkema, Rotterdam, Netherlands, 329-34

Kamel, H., Eita, T., Sarhan, M., 1998. Nile delta hydrocarbon potentiality, Egypt, E.G.P.C. 14th Exploration and Production Conference, 2, 485-503.

Monir, M., and Shenkar, O., 2017. Pre-Messinian petroleum system and trapping style, offshore western Nile Delta, Egypt. In AAPG-SPE Africa Energy and Technology Conference, 5-7.

Nashaat M., 1992. Geopressure and Geothermal Studies Nile Delta, Egypt. M.Sc., Faculty of Science, Al Azhar University, Cairo, 133pp.

Safa, M. G., Sarhan, M. A., 2017. Application of seismic attributes for detecting different geologic features within Kafr El-Sheikh Formation, Temsah Concession, Nile Delta Basin, Scientific Journal for Damietta, Faculty of Science, 7 (1), 26-34.

Safa, M. G., Sarhan, M. A., 2019. 2D Seismic interpretation and hydrocarbon prospects for the NeogeneQuaternary succession in the Temsah Field, offshore Nile Delta Basin, Egypt, Journal of African Earth Sciences, 155, 1-12.

Samuel, A., Kneller, B., Raslan, S., Sharp, A., and Parsons, C., 2003. Prolific deep-marine slope channels of the Nile Delta, Egypt. American Association of Petroleum Geologists Bulletin, 87, 542.

Sarhan, M. A., and Safa, M. G., 2019. 2D seismic interpretation and hydrocarbon prospects for the NeogeneQuaternary succession in the Temsah Field, offshore Nile Delta Basin, Egypt. Journal of African Earth Sciences, 155, 1-12.

Schlumberger, 1984. Well evaluation conference. Egypt, Schlumberger, Middle East, 1-64

Sestini, G., 1989. Nile Delta: A Review of the Depositional Environments and Geological History, In: In Whateley, M.K.G., Pickering, K.T. (Eds.), Deltas: Sites and Traps for Fossil Fuels. Geological Society, London, 41, $100 \mathrm{pp}$.

Sharaf, E., Korrat, I., Seisa, H., and Esmail, E, 2014.Seismic imaging and reservoir architecture of sub-marine channel systems offshore, West Nile Delta of Egypt. Open Journal of Geology, 4, 730.

Vail, P. R., Mitchum, R. M., Todd, R. G., Widmier, J.M., Thompsom, S., Sangree, J.B., Bubb, J.N., Hailelid, W.G., 1977a. Seismic stratigraphy and global changes in sea level. In: Payton CE (ed) Seismic stratigraphyapplications to hydrocarbon exploration. AAPG Memoir, American Association of Petroleum Geologists, Tulsa, 26, 49-212. 